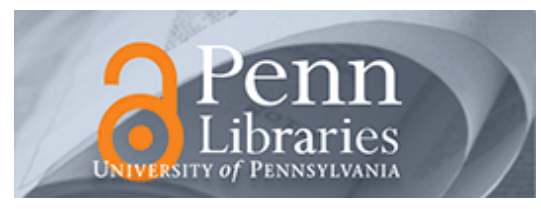

University of Pennsylvania

ScholarlyCommons

Health Care Management Papers

Wharton Faculty Research

4-1993

\title{
Comment on Epstein, "Holdouts, Externalities, and the Single Owner: One More Salute to Ronald Coase"
}

Patricia. M. Danzon

University of Pennsylvania

Follow this and additional works at: https://repository.upenn.edu/hcmg_papers

Part of the Economic Theory Commons, and the Other Education Commons

\section{Recommended Citation}

Danzon, P. M. (1993). Comment on Epstein, "Holdouts, Externalities, and the Single Owner: One More Salute to Ronald Coase". The Journal of Law and Economics, 36 (1), 587-594. http://dx.doi.org/10.1086/ 467290

This paper is posted at ScholarlyCommons. https://repository.upenn.edu/hcmg_papers/114

For more information, please contact repository@pobox.upenn.edu. 
Comment on Epstein, "Holdouts, Externalities, and the Single Owner: One More Salute to Ronald Coase"

\author{
Disciplines \\ Economic Theory | Other Education
}


Articles from 2013 and after

THE L AW SCHOOL.

are now only accessible on

the Chicago Journals website at

JOURNALS.UGHIGAGO.EUU

\section{The Booth School of Business, University of Chicago}

Comment on Epstein, "Holdouts, Externalities, and the Single Owner: One More Salute to Ronald Coase"

Author(s): Patricia Danzon

Source: The Journal of Law \& Economics, Vol. 36, No. 1, Part 2, John M. Olin Centennial

Conference in Law and Economics at the University of Chicago (Apr., 1993), pp. 587-594

Published by: The University of Chicago Press for The Booth School of Business,

University of Chicago and The University of Chicago Law School

Stable URL: http://www.jstor.org/stable/725491

Accessed: 06-06-2016 20:16 UTC

\section{REFERENCES}

Linked references are available on JSTOR for this article:

http://www.jstor.org/stable/725491?seq=1\&cid=pdf-reference\#references_tab_contents You may need to log in to JSTOR to access the linked references.

Your use of the JSTOR archive indicates your acceptance of the Terms \& Conditions of Use, available at

http://about.jstor.org/terms

JSTOR is a not-for-profit service that helps scholars, researchers, and students discover, use, and build upon a wide range of content in a trusted digital archive. We use information technology and tools to increase productivity and facilitate new forms of scholarship. For more information about JSTOR, please contact support@jstor.org.

The University of Chicago Press, The Booth School of Business, University of Chicago, The University of Chicago Law School are collaborating with JSTOR to digitize, preserve and extend access to The Journal of Law \& Economics 


\title{
COMMENT ON EPSTEIN, “HOLDOUTS, EXTERNALITIES, AND THE SINGLE OWNER: ONE MORE SALUTE TO RONALD COASE"*
}

\author{
PATRICIA DANZON \\ University of Pennsylvania
}

$\mathrm{R}$

ICHARD EPSTEIN's thoughtful and thought-provoking article is an ambitious attempt to provide a unified approach to the question of allocation of rights in a world of nonzero transactions costs. His central thesis is that "the choice of the legal rule, whether by social command or private trade-off, typically turns on a trade-off between two separate impediments to complete contingent-state contracts. . . . The first of these is the problem of externalities. The second is the problem of holdouts. . . In my view, the purpose of all legal rules is to minimize the sum of the costs that are associated with these two forms of bargaining obstacles." 1

As Epstein acknowledges, externality and holdout problems have been extensively examined separately. His contribution is to point out their pervasiveness and, more important, their inverse relationship. "All imperfections, then, come in only two basic forms. . . . The essential dilemma is that often the effort to counteract one problem will only aggravate the other, for where both are present, they stand in an inverse relationship with each other.", 2 The reason is that if consent of affected parties is not required, externalities may occur. Externalities can be prevented by requiring consent of all affected parties, but only at the cost of creating the potential for holdouts.

Faced with these potential costs, Epstein argues that courts should-

\footnotetext{
* Presented at the John M. Olin Centennial Conference in Law and Economics at the University of Chicago Law School, April 7-9, 1992. The author is a Celia Moh Professor, Departments of Health Care Systems and Insurance, the Wharton School of the University of Pennsylvania.

${ }^{1}$ Richard A. Epstein, Holdouts, Externalities, and the Single Owner: One More Salute to Ronald Coase, in this issue, at 557.

${ }^{2} I d$.
}

[Journal of Law \& Economics, vol. XXXVI (April 1993)]

(C)1993 by The University of Chicago. All rights reserved. 0022-2186/93/3601-0026\$01.50 
and apparently usually do-minimize the sum of the costs related to externalities and holdouts. This, he argues, is equivalent to applying a "single owner" test. The single owner would allocate resources in a way that maximizes value (ignoring distributional effects). When applying this test to situations of potential conflict between multiple parties when cooperation between them is precluded, the mandate is to maximize the joint value of the resources, net of transactions costs.

Epstein proceeds to a normative and positive analysis of various areas of property law related to "physical invasions," concluding in most cases that the common-law rules can be explained by his simple rules. The only limits to the reach of these principles in determining optimal rules arise from the limits of the insights provided by the single owner test. Epstein concludes, "In those cases in which a single owner test yields a unique result, then it is the one that should be followed by the legal system. Yet in those cases in which the single owner test does not yield clear results, then there will be no principle that will yield a decisive answer to the particular problem at hand.",3

Epstein's proposed rule - to minimize the sum of costs associated with externalities and holdouts-is offered as a salute to Ronald Coase. But at first sight, it seems at odds with Coase's basic message about the fundamental importance of defining property rights. Externalities presumably exist only where property rights are not defined, whereas holdouts arise where property rights are defined, as part of the process of determining the price at which they will be transferred. Following Coase, it would seem that externalities are always the greater evil, as a general principle, since if rights are not defined, negotiations over the transfer of resources to their highest-valued use are unlikely even to get started. In fact, Epstein's discussion refers to situations in which rights are always defined: the comparison is between alternative allocations. Externalities arise when one party is entitled to take unilateral actions without the consent of other affected parties; holdouts arise where consent of all parties is required.

Paraphrasing, the sole owner principle is equivalent to positing a utilitarian (additive) social welfare function. An additional implicit assumption is that all individuals are risk neutral. The social objective then reduces to maximization of the net value derived from the use of resources, which is the gross value minus the transactions costs of effecting the transfer to the highest-valued use. Thus, Epstein's rule is simply a rule for efficient resource allocation. The "externality" costs are deadweight

${ }^{3}$ Id. at 561 . 
costs from resource misallocation. With respect to the "holdout costs," Epstein implicitly assumes that they are pure waste. A broader view of transactions and contracting costs would recognize that in a multiparty world, information may be imperfect. Transactions costs then include the costs of obtaining and transferring information about resource value in alternative uses.

This is not a trivial extension since it introduces the possibility that, from an ex ante perspective, externalities may potentially be bilateral (that is, affect both parties) and hence that some transactions expenditures should be viewed as productive investments in information rather than pure deadweight loss, as implied by the term "holdout." The legal rule should be designed to encourage an efficient investment (by both parties where relevant) in information and transfer of property to highervalued uses. If incremental rather than all-or-nothing changes are possible, the social optimum requires that, at the margin, the "holdout" cost of additional information is just equal to the reduction in deadweight loss due to resource misallocation.

Stated in this way, the problem of defining optimal rules to govern invasions of physical property is exactly analogous to the tort problem of designing optimal rules to govern personal injuries. The externality costs are the analog of the injury costs, the holdout or information costs are the analog of costs of precautions. ${ }^{4}$ Investing in information reduces the externality costs, just as investment in precautions reduces accident costs. Thus, the production framework first applied by Brown ${ }^{5}$ to the accident problem applies, to the broad range of contexts reviewed by Epstein, with minor modifications: output is now the increment in resource value, inputs are information and other contracting inputs.

Pursuing this analogy, assigning the right to the highest-valued user with no requirement of consent from the other party (for example, ownership of the cave to the owner of the mouth) is analogous to a rule of no liability. Requiring consent or compensation (or removal of the offending property in the case of encroachment) is analogous to strict liability.

It is well known that these extreme liability rules lead to a first-best outcome only for "single activity" accidents, that is, in circumstances where efficient accident prevention requires care by only one party. Similarly, it can be shown that the extreme property rules are first best only in circumstances where one type of use is always superior. More gener-

\footnotetext{
${ }^{4}$ It is noteworthy that the transactions costs associated with generating information are here elevated to a major role, in contrast to the neglect that such costs typically receive in models of tort law.

${ }^{5}$ John P. Brown. Toward an Economic Theory of Liability, 2 J. Legal Stud. 323 (1976).
} 
ally, which use of a property generates the highest value depends on the circumstances; for example, it may sometimes be more efficient to assign ownership of a cave to the owner of the surface land above the cave rather than to the owner of the mouth. Thus, in the more general case, the external effects can go in either direction (as in bilateral accidents), and moral hazard or strategic behavior can also be bilateral. Efficiency requires some investment in information to discover the highest-valued use.

The analogy between the property rights problem and the more familiar accident problem may be stated formally. Let $Y$ and $L$ denote the value of the resource to A and $\mathrm{B}$, respectively, with $Y>L$. Let $x$ and $z$ denote investment by $\mathrm{A}$ and $\mathrm{B}$, respectively, on negotiating and other activities related to transfer of resources between them. The cost per unit of $x$ and $z$ is $\$ 1$. The probability that a resource is transferred to its highest-valued use (in this case $\mathrm{A}$ ) is $p(x, z)$. Let us assume that $p_{x}>0$ and $p_{z}<0$; that is, $x$ increases the probability of transfer, $z$ decreases the probability, and so could be called holdout costs. Alternatively, $z$ could affect the perceived value of the resource.

The social welfare problem is to maximize the expected value of the resource, net of transactions costs:

$$
\max _{x, z} \mathrm{SW}=p(x, z)(Y-L)-x-z
$$

where $p$ can be interpreted as the frequency of transfer of resources to their highest-valued use.

The first-order condition for the socially optimal level of $x$ is

$$
p_{x}\left(z^{*}\right)[Y-L]=1 \text {. }
$$

Thus, investment in effecting transfer to use A should be incurred up to the point where the marginal transacting cost is just equal to the expected gain in increased value of output.

The first-order condition for $z$ is

$$
p_{z}\left(x^{*}\right)[Y-L]=1 .
$$

Adopting Epstein's assumption that B's negotiating effort is pure waste, that is, it is known that $Y>L$ and hence that $p_{z}<0$, the optimal level of $z\left(z^{*}\right)$ is zero. In the more general case where $z$ generates information about the value of the resource to $\mathrm{B}$, the formulation of the problem is more complex and the optimal level of $z$ is not zero.

The issue is, What rights should be assigned to B? Epstein considers two basic alternatives: $(a)$ the right is assigned to A (presumptively the highest-valued use) with no consent or compensation requirement, which 
is analogous to the tort rule of no liability, or $(b)$ B's consent (or, by implication, full compensation) is required, which is analogous to strict liability.

As in the tort case, these extreme rules generally do not assure a firstbest outcome. Consider first the analog of "no liability," whereby A is not required to compensate B, that is, any externality is permitted. A selects $x$ to maximize his private interest $\mathrm{PW}^{\mathrm{A}}$ :

$$
\max \mathrm{PW}^{\mathrm{A}}=p(x, z) Y-x .
$$

The first-order condition is

$$
p_{x}(0) Y=1 .
$$

Comparing equation (5) with equation (2), it is clear that if $\mathrm{A}$ is not required to compensate $\mathrm{B}, \mathrm{A}$ invests in transfer activity to the point where the marginal transfer cost is equal to the expected gross gain, ignoring the loss to $\mathrm{B}$. Thus, the allocation of resources to A-type uses is too high. Since B would have no incentive to invest in $z$, there would be no expenditure on holdouts but also no transfer of information about the loss incurred by $\mathrm{B}$.

Alternatively, under the analog of strict liability, $\mathrm{A}$ is required to compensate $B$ or remove any encroachment. $B$ has incentives to spend on $z$ to increase the perceived value of $L=L+d L(z)$. When B is entitled to compensation, his incentive is to maximize his expected compensation, net of negotiation costs:

$$
\max _{z} \mathrm{PW}^{\mathrm{B}}=p(x)(L+d L(z))-z .
$$

The first-order condition is

$$
p(x) d L_{z}=-1 .
$$

Thus, if the potential payoff to $z$ is positive $\left(L_{z}>0\right)$, B invests in $z$ to increase his expected compensation. This is the holdout problem. A's private objective function is

$$
\max \mathrm{PW}^{\mathrm{A}}=p(x, z)[Y-L-d L(z)]-x,
$$

with first-order condition

$$
p_{x}[Y-L-d L(z)]=1 .
$$

This would be socially optimal only if $d L=z=0$. But if $z>0$ because B "holds out" for higher compensation by exaggerating his true value of $L$, then the transfer of resources to A-type uses will be suboptimal.

Thus, a rule that requires full compensation or no compensation is 
never first-best optimal if both sides have incentives to spend resources, A on increasing the probability (frequency) of transfer and B on increasing his expected compensation from the transfer.

Consider first the choice of optimal rule when only these all-or-none rules are possible. The rule requiring no consent or compensation of $B$ by A leads to a first best only if A's use imposes no externality on B; if this condition is not met, then the optimal rule depends on the extent of moral hazard by both sides, which depends on $p_{x}$ and $L_{z}$. A rule of no consent is the solution that Epstein advocates for caves: assign all rights to the owner of the mouth, none to the owner(s) of the surface land over the cave. But if A's use of the cave imposes externalities on B, for example, due to subsidence or disturbance of surface land, and the supply of caves is not perfectly inelastic, there will be too many caves and too much interference with surface owners' rights.

By contrast, in the case of encroachments, Epstein assumes an elastic supply of encroachments ( $p_{x}$ is high) and therefore opts for the other extreme rule of assignment of all rights to B. However, like strict liability, this rule also leads to first-best outcomes only in restrictive circumstances. As Epstein points out, a rule requiring full compensation or removal of encroachments is more likely to be optimal if the supply of encroachments is highly elastic. However, the elasticity of supply of $z$ and the productivity of $z$ in raising $L$ are also factors to be considered. Potentially efficient transfers will be abandoned if seller demands $(L+$ $d L(z))$ are sufficiently large to eliminate all expected return to A, net of compensation and own bargaining expense:

$$
p(x)[Y-L-d L(z)]-x \leq 0 .
$$

Presumably, this is unlikely in the two-person bilateral monopoly case. But the likelihood that transactions costs block a value-increasing transfer increases as the number of sellers increases, conditional on the aggregate value of $L$. In that case, each seller can hold out for the total increase in value due to the transfer, and the sum ${ }^{6}$ of these maximum demands exceeds $Y$. Thus, ceteris paribus, as the number of sellers increases, holding constant the aggregate value to the buyer, the expected holdout costs increase, and the rule requiring unanimous consent becomes increasingly less likely to be even a second best.

As in the case of tort liability for accidents, circumstances are often such that there is no rule that universally dominates: externalities may flow in both directions, and optimal investment in negotiations to deter-

${ }^{6}$ For a discussion of this rationale for eminent domain, see Patricia Danzon, An Economic Analysis of Eminent Domain (1976). 
mine the highest-valued use is nonzero. As with accidents that require bilateral "care," first-best allocations of property resources may require more complex rules. The analog of strict liability with a contributory negligence defense would be that A should compensate B only if $z=z^{*}$; that is, B does not exaggerate or act strategically to obstruct the transfer. The analog of negligence with a contributory negligence defense would be that $\mathrm{A}$ should compensate $\mathrm{B}$ if $\mathrm{A}$ invests unreasonably $\left(x>x^{*}\right)$, provided that $\mathrm{B}$ did not behave strategically $\left(z=z^{*}\right)$. Simple negligence would just drop the condition on $z$.

These rules place higher information requirements on the courts than the simple all-or-nothing rules. They require the courts to determine whether A has engaged in moral hazard or B has acted strategically with exaggerated demands for compensation. But the information required to choose between the two simple rules is not trivial-Epstein's assertions to the contrary notwithstanding.

The analogy between optimal rules for property invasions and optimal rules for accidents may be extended further. Just as efficient accident prevention often requires conditions on the rate of harmful activities by both parties and on the care per unit of activity, ${ }^{7}$ similarly, efficient allocation of property requires conditions on both ownership and the frequency or extent of use. For example, even if ownership of caves is optimally assigned to the owner of the mouth, efficiency may require some restrictions on use, if some uses inflict costs on surface owners. It would be a simple matter to extend the formal model to include these additional dimensions. But the conclusion, as in the tort case, is likely to be that simple rules are even less likely to lead to first-best outcomes, once the multidimensional and bilateral nature of the interactions is taken into account.

In my discussion, I have intentionally used the terminology of efficiency rather than the single owner. In multiparty conflicts, the single owner terminology begs the question of whose preferences this owner adopts if the preferences of the parties differ. Thus, the single owner principle is unambiguous only in circumstances in which preferences are similar and wealth effects of property right assignment are small. More generally, the allocation of rights affects the distribution of wealth, and this in turn may affect the valuation of alternative resource allocations. For example, if the surface owner were assigned the right to the cave, the highest-valued use might be to leave it undeveloped, if he values very highly the privacy and tranquility that is destroyed when it is exploited

${ }^{7}$ Steven Shavell, Strict Liability versus Negligence, 9 J. Legal Stud. 1 (1980). 
for tourism. The assignment of ownership to the owner of the mouth of the cave would create, not eliminate, a holdout problem since now the surface owner would have to negotiate to acquire the right to eliminate tourism. This underscores the more general point, that the valuemaximizing use of a resource may itself depend on the distribution of rights. Thus, it may be circular to look to value maximization to determine the optimal distribution of rights, where this distribution has wealth effects that in turn affect the overall value of resources.

If wealth effects are negligible, then net wealth maximization is either always or never the correct criterion to apply in principle, depending on the structure of the social welfare function. The obstacles to its application in practice are the empirical difficulties of determining the relevant costs and benefits. This ambiguity may hold more generally than Epstein acknowledges. Thus, whereas Epstein envisages two sets of circumstances, those that can and those that cannot be resolved unambiguously by appeal to the single owner principle, I believe that wealth maximization is in principle always applicable but that empirical difficulties may preclude clear-cut answers in many cases. In other words, the information requirements for determining the optimal rule vary among contexts, but are rarely zero or infinite, as Epstein's dichotomy implies. Of course, Epstein may dismiss more complex rules as hopelessly costly to implement. That is a judgment about which reasonable people may differ. Empirical hunches about the efficiency of alternative legal rules are, like beauty, often in the eye of the beholder.

In summary, Epstein has proposed a useful unifying framework for evaluating the efficiency of alternative property rules. I believe that more careful theoretical and empirical analysis is required in order to substantiate the normative conclusions preferring certain rules over others and the positive conclusions that actual rules conform to these normative prescriptions. This is in no way a criticism of Epstein's framework; rather, it is a call for extending and developing it.

\section{BIBLIOGRAPHY}

Munch, Patricia. "An Economic Analysis of Eminent Domain.' Journal of Political Economy 84, no. 3 (1976): 473-98.

Shavell, Steven. "Strict Liability versus Negligence.' Journal of Legal Studies 9 (1980): 1-26. 